\title{
The correlation analysis between ant mounds and plant resource in Olkhon region
}

\author{
(c) Xu Wang ${ }^{a}$, Qingxi Hu ${ }^{b}$, Weizheng Kong ${ }^{c}$, Chenyang Zhang ${ }^{d}$, Shan Jiae, Yuan Changf, \\ Wei Deng ${ }^{g}$, Andrey V. lishtvah, Victor G. Shilenkovi, Zhongqiu Lij, Xingjun Tiank \\ a-g,j,kNanjing University, Nanjing, China \\ h, Irkutsk State University, Irkutsk, Russia
}

\begin{abstract}
Olkhon region in East Siberia has abundant and unique vegetation and animal resource for its peculiar geographic location, including ants. Ant, recognized as ecosystem engineers, has an important role in ecosystem. In order to investigate the ecological role of mound-building ants in this region, we focused our attention on the correlation between the distribution of ant mounds and plant species. Five quadrats $(5 \mathrm{~m} \times 5 \mathrm{~m})$ were set up in this region, each of which was then divided into twenty-five quadrats $(1 \mathrm{~m} \times 1 \mathrm{~m})$. We collected the location of every Black Bog Ant (Formica candida) mound, the number and biomass of various plants in every small quadrat. Using matrices, we tested the distribution pattern of ant mound randomly. The correlation between plants and ant mound pattern was tested by correlation analysis and regression analysis. The result showed that the spatial distribution of ant mound was random. We also found that Artemisia frigida, Carexduriuscula and Oxytropis sylvesfris had a significant linear relationship with the spatial distribution of ant mound $(P<0.05)$, suggesting that the spatial distribution of ant mound was dependent on the spatial distribution of some plants. The underlying mechanism was further studied. We attributed this correlation to the feeding habits and foraging strategies of Black Bog Ant and tissue structure of these three plants. Our study figured out the interaction between Black Bog Ant and plant resource in Olkhon region, laying down the foundation for future study on the co-evolution of plant and animal resource in this unique ecosystem.
\end{abstract}

Keywords: ant mounds, spatial distribution pattern, plant biodiversity, correlation analysis, Olkhon region Information about the article: received June 25, 2020; revised July 30, 2020; accepted August 21, 2020.

For citation: Wang Xu, Hu Qingxi, Kong Weizheng, Zhang Chenyang, Jia Shan, Chang Yuan, et al. The correlation analysis between ant mounds and plant resource in Olkhon region. Nauki o Zemle i nedropol'zovanie = Earth sciences and subsoil use. 2020;43(3):436-446. (In Russ.) https://doi.org/10.21285/2686-9993-2020-43-3-436-446

\section{Корреляционный анализ между размещением муравейников и растительными ресурсами в Ольхонском регионе}

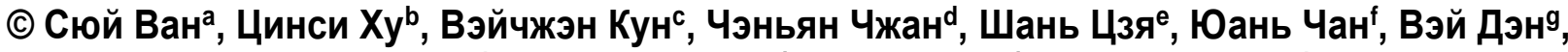 \\ А.В. Лиштва', В.Г. Шиленков', Чжунцю Ли', Синзюнь Тянь ${ }^{\mathrm{k}}$ \\ a-g.j,kнанкинский университет, г. Нанкин, Китай \\ h,Иркутский государственный университет, г. Иркутск, Россия
}

\begin{abstract}
Резюме: Ольхонский регион как часть Восточной Сибири обладает богатыми и уникальными растительными и животными ресурсами благодаря специфическому географическому положению. Муравьи, в свою очередь, являются важной составной часть экосистемы и играют в ней важную роль. В целях исследования экологической роли муравьев-строителей в этом регионе авторы данной статьи обратили внимание на корреляцию между расположением муравейников и видами растений. В районе исследований были выбраны пять пробных площадей (5 м × 5 м), каждая из которых затем была разделена на двадцать пять квадратов (1 м × 1 м). Отмечалось местонахождение каждого муравейника, сооруженного Formica candida, количество, видовой состав и биомасса различных растений в каждом малом квадрате. С использованием матриц случайным образом тестировалась картина распределения муравейников. Корреляцию между растениями и расположением насыпей муравьев проверяли с помощью корреляционного и регрессионного анализа. Результат показал, что пространственное распределение муравейников оказалось случайным. Также было обнаружено, что растения Artemisia frigida, Carex duriuscula и Oxytropis sylvestris имели значительную линейную связь с пространственным распределением муравейников $(P<0,05)$, предполагается, что пространственное распределение муравейников зависит от пространственного распределения некоторых растений. Авторы связали эту корреляцию с привычками питания и стратегиями старения черного болотного муравья, а также со структурой тканей указанных трех видов растений. Проведенное
\end{abstract}


исследование выявило взаимодействие между муравьем и некоторыми видами растений в Ольхонском регионе и может являться основой для будущих исследований совместной эволюции растительных и животных ресурсов в этой уникальной экосистеме.

Ключевые слова: муравейники, пространственное распространение, биоразнообразие растений, корреляционный анализ, Приольхонье

Информация о статье: поступила в редакцию 25 июня 2020 г.; поступила после рецензирования и доработки 30 июля 2020 г.; принята к публикации 21 августа 2020 г.

Для цитирования: Ван Сюй, Ху Цинси, Кун Вэйчжэн, Чжан Чэньян, Цзя Шань, Чан Юань [и др]. Корреляционный анализ между размещением муравейников и растительными ресурсами в Ольхонском регионе. Науки о Земле и недропользование. 2020. Т. 43. № 3. С. 436-446. https://doi.org/10.21285/2686-9993-2020-43-3-436-446

\section{Introduction}

Olkhon region, located on the western shore of Lake Baikal in East Siberia, has a combined climate pattern of continental climate and maritime climate due to the huge water body of Lake Baikal. Its unique climate pattern and topography nurture rich biological resources, including some endemic species. A total of 118 families and 494 genera of vascular plants have been recorded in this area. Among them, Asteraceae, Poaceae, and Cyperaceae are the main families, and they account for $51 \%$ of genera and $59 \%$ of species. Animal resources are also abundant, with more than 1,600 aquatic animal species.

Among commonly spotted animals, ant, the highly socialized hymenopteran, is recognized as one of the most important arthropods in the soil who plays a vital role in ecosystem. The foraging behavior of ants plays an important role in the food web and energy cycle. It changes the flow of matter and energy - organic matter is buried deeper, small particles are brought to the surface, soil porosity is increased, moisture is dispersed and gas is released [1, 2]. The ant mounds surface is also rich in $\mathrm{C}, \mathrm{N}$ and other elements [3]. These physical and chemical changes will affect the soil microenvironment and nutrient cycling, and then affect the structure of plant resources. Studies have proven that ants have formed a symbiotic relationship with many plants in a longterm evolution process [4]. For example, ants can help spread plant seeds and to some extent affect the community structure of some temperate forests [4]. On the other hand, plants provide food and habitat for ants. The reciprocal relationship between the ants and plants not only facilitates the restoration of natural communities, but also promotes their evolution. For these reasons, international studies have used ants as a biological indicator to detect environmental and biodiversity changes $[5,6]$. However, the current research on ants mainly focuses on taxonomy, fauna and biodiversity [7]. Studies on other aspects, especially the correlation between their mound-building activities and plants are still very few.

Meanwhile, the spatial distribution pattern of insect populations is an important property of the population [8]. The spatial pattern of the population shows the distribution of individual in the horizontal space, which is the combinational result of the population characteristics, interspecies relationships, and environmental conditions [9]. It also reflects the population dynamics and community succession trend [10]. Therefore, the spatial distribution pattern of ant mounds is a good indicator of ant mound-building activity.

In this study, we investigated the spatial distribution pattern of Black Bog Ant (Formica candida), the dominant ant species in Olkhon region, and the distribution structure of plant resources. We set up a correlation model for the distribution of Black Bog Ant mounds and plants to explore their interaction.

\section{Material and methods}

The investigation was conducted on five $5 \mathrm{~m} \times 5 \mathrm{~m}$ grassland at Chernorud Camp, Olkhon. Each quadrat was divided into $1 \mathrm{~m} \times 1 \mathrm{~m}$ quadrats. Location of ant mounds, along with the quantities and biomass of plant species were recorded. Biomass was calculated based on the average weight of 3 individuals after air drying.

We used the $K$ function with the spatstat language pack of the statistic software $R$ (3.5.2) to study the spatial distribution of the ant mounds $[11,12]$. $K$ function was put forward by Ripley [13]:

$$
\hat{K}(r)=\frac{A}{n^{2}} \sum_{\boldsymbol{d}_{i=1}}^{n} \sum_{\substack{j=1 \\ j \neq 1}}^{n} w_{i j}^{-1} I_{r}\left(u_{i j}\right) .
$$


A represents the area of the quadrat, $n$ represents the number of the ant mound in the quadrat, $u_{i j}$ represents the distance between the ant mound $i$ and $j$, and $w_{i j}$ represents weighting, which is used to eliminate the Edge Effect. Noticeably, when $u_{i j} \leq r, I_{r}\left(u_{i j}\right)=1$, and when $u_{i j}>r$, $I_{r}\left(u_{i j}\right)=0$.

We used Monte Carlo method with R (3.5.2) to generate the upper and lower envelop curve at random [14]. The number of the data point was the same with the observation point. If $K(r)$ falls between two envelop curves, the ant mound resigns to random distribution. If it is over the upper envelop curve, the ant mound resigns to clumped distribution. If it falls below the lower envelop curve, the ant mound resigns to uniform distribution [15].

Correlation analysis uses the Nonparametric tests to test significant difference between distributions of two population. In this experiment, the analysis was done by applying Spearman Analysis whose function is shown below [16].

$$
\rho=\frac{\sum_{i=1}^{n}\left(x_{i}-\bar{x}\right)\left(y_{i}-\bar{y}\right)}{\sqrt{\sum_{i=1}^{n}\left(x_{i}-\bar{x}\right)^{2} \sum_{i=1}^{n}\left(y_{i}-\bar{y}\right)^{2}}} .
$$

$\mathrm{Lm}$ function with $\mathrm{R}$ 3.5.2 was applied for the multiple regression analysis. Full regression model of the total biomass of all collected plants against the number of the ant mound in quadrats was established. The variance inflation factor (VIF) was used to determine collinearity. We defined multicollinearity when VIF $>5$. Stepwise regression was done by applying Step function for preliminary screening for variables and modeling with those candidates according to Akaike information criterion (AIC). Afterwards multiple regression model of the total biomass of the collected plants and the ant mound was established by the total biomass of each plant species. This model identified the plant species that have greater effect on the ant mound distribution in the overall environment and their corresponding effect.

\section{Results}

Figure 1 presents 188 F.candida mounds, including 20 from quadrat $a, 17$ from quadrat $b, 40$ from quadrat $c, 35$ from quadrat $d$ and 76 from quadrat $e$.

According to the result of the $K$ Function (Fig. 2), Kobs values (the actual value of $K(r)$ ) of quadrat $1-3,5$ lie inside the envelope, so the ant mounds in these four quadrats are randomly distributed on the scale of $0-1.2 \mathrm{~m}$. The result of quadrat 4 displays a different result. Ant mounds are clustered on the scale of $0-1 \mathrm{~m}$, but resign to random distribution on a broader scale.

We identified 25 plant species at Chernorud Camp and yielded the biomass of each plants. Based on the biomass, we conducted correlation analysis by Spearman (Table 1). The results show that the biomass of Artemisia frigida $\left(\rho_{6}=\right.$ $0.442, P=0.038)$, Carex duriuscula $\left(\rho_{10}=-0.367\right.$, $P=0.029)$ and Oxytropis sylvestris $\left(\rho_{19}=-0.287\right.$, $P=0.031$ ) have significant correlation with the distribution of ant mounds. The biomass of Artemisia frigida is positively correlated with ant mounds, while the biomass of the other two plants, Carex duriuscula and Oxytropis sylvestris has negative correlation individually. The result suggests extensive interaction between these three plants and ant mounds.

Shannon-Wiener biodiversity index and Simpson biodiversity index were selected as indicators of plant biodiversity to correlate with ant mounds on different scales. On the small scale $(1 \mathrm{~m} \times 1 \mathrm{~m})$, the correlation coefficient of Shannon-Wiener biodiversity index ( $\rho s-w)$ is $0.157(P=$ $0.08)$ and that of Simpson biodiversity index ( $\rho$ Simpson) is $0.165(P=0.067)$. Although the $P$ values are all greater than 0.05 , we still suppose that the spatial distribution of ant mounds and plant biodiversity tend to have a positive correlation.

When the scale comes to $5 \mathrm{~m} \times 5 \mathrm{~m}$, the $P$ values are greater than 0.1 (Table. 2 ), suggesting that the spatial distribution of ant mounds has no correlation with plant biodiversity.

To exclude the influence of the possible correlations between variables, we further conducted the multiple regression analysis. We identified plant species that have multicollinearity, and chose the smallest model which contained the biomass of 8 plant species as independent variables by the stepwise regression (Table. 3 ). The output of the model after stepwise regression show that the distribution of ant mounds is positively correlated with the biomass of O.spinosa, C.daurica, A.commutata and A.frigida, while is negatively correlated with the biomass of P.ambigua, C.squarrosa, O.sylvestris and C.duriuscula. 

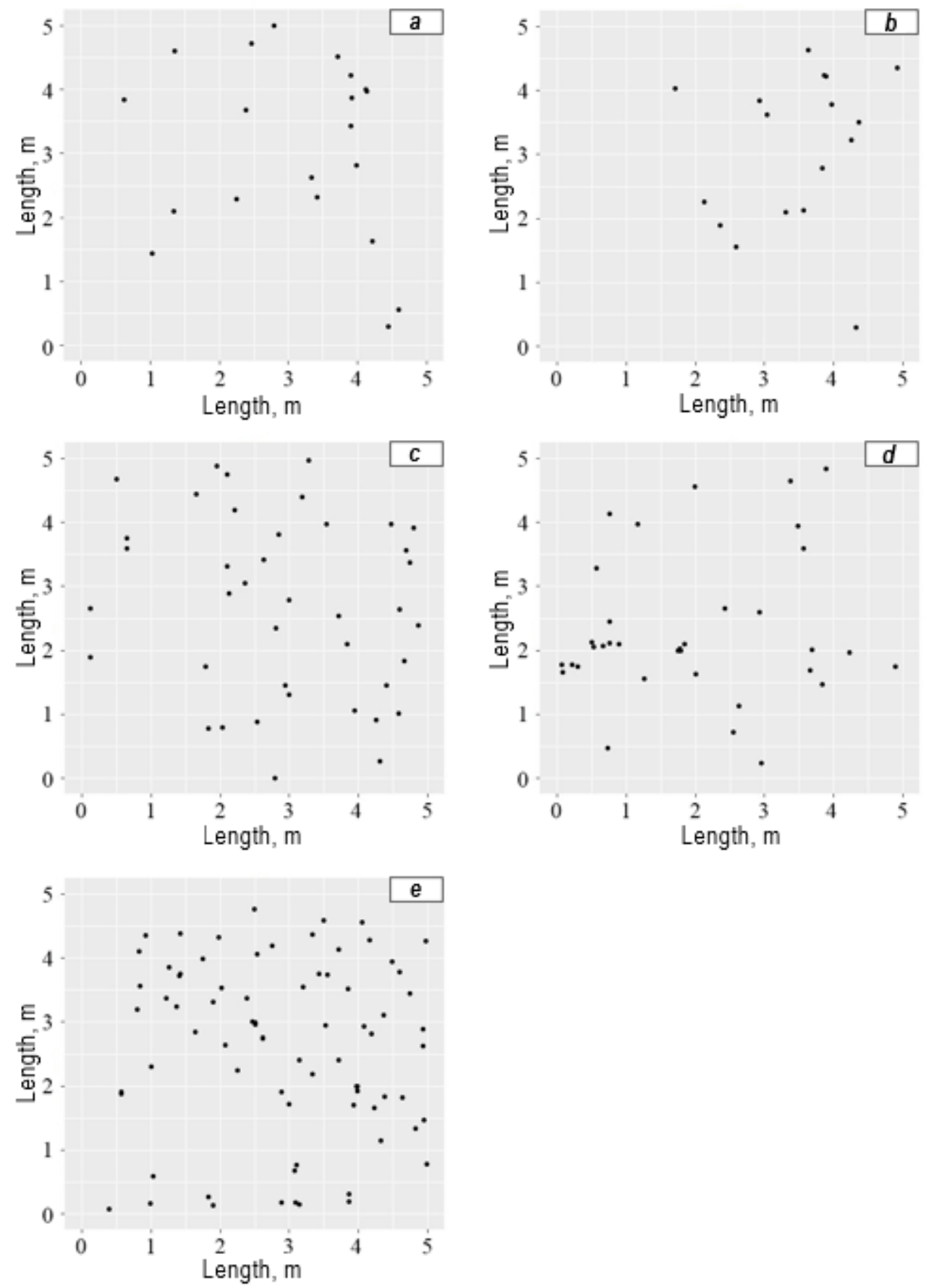

Fig. 1. Distribution of ant mounds

Quadrat numbers (a-e) are marked in each plot

Puc. 1. Распределение муравейников на пяти пробных площадях На каждом из графиков отмечены числа квадрата (a-e)

Comparing the standard coefficients with each plants, A.frigida $(P=0.031)$, O.sylvestris $(P=0.018)$ and $C$.duriuscula $(P=0.001)$ have significant influence on the distribution of ant mounds. The result is consistent with that obtained from the correlation analysis.

The output of the model can be concluded as following:

$$
\begin{gathered}
Y=1.829+0.019 X_{\text {o.spinosa }}+0.179 X \\
\text { C.daurica }-0.063 X_{\text {P.ambigua }}-0.703 X \\
\text { C.squarrosa }+0.047 X_{\text {A.commutata }}+0.060 X \\
\text { A.frigida }-0.062 X \text { O.sylvestris }-0.063 X \text { C.duriuscula }
\end{gathered}
$$

\section{Discussion}

In this study, by collecting the relevant data of plants and ant mound in Olkhon, we tried to 

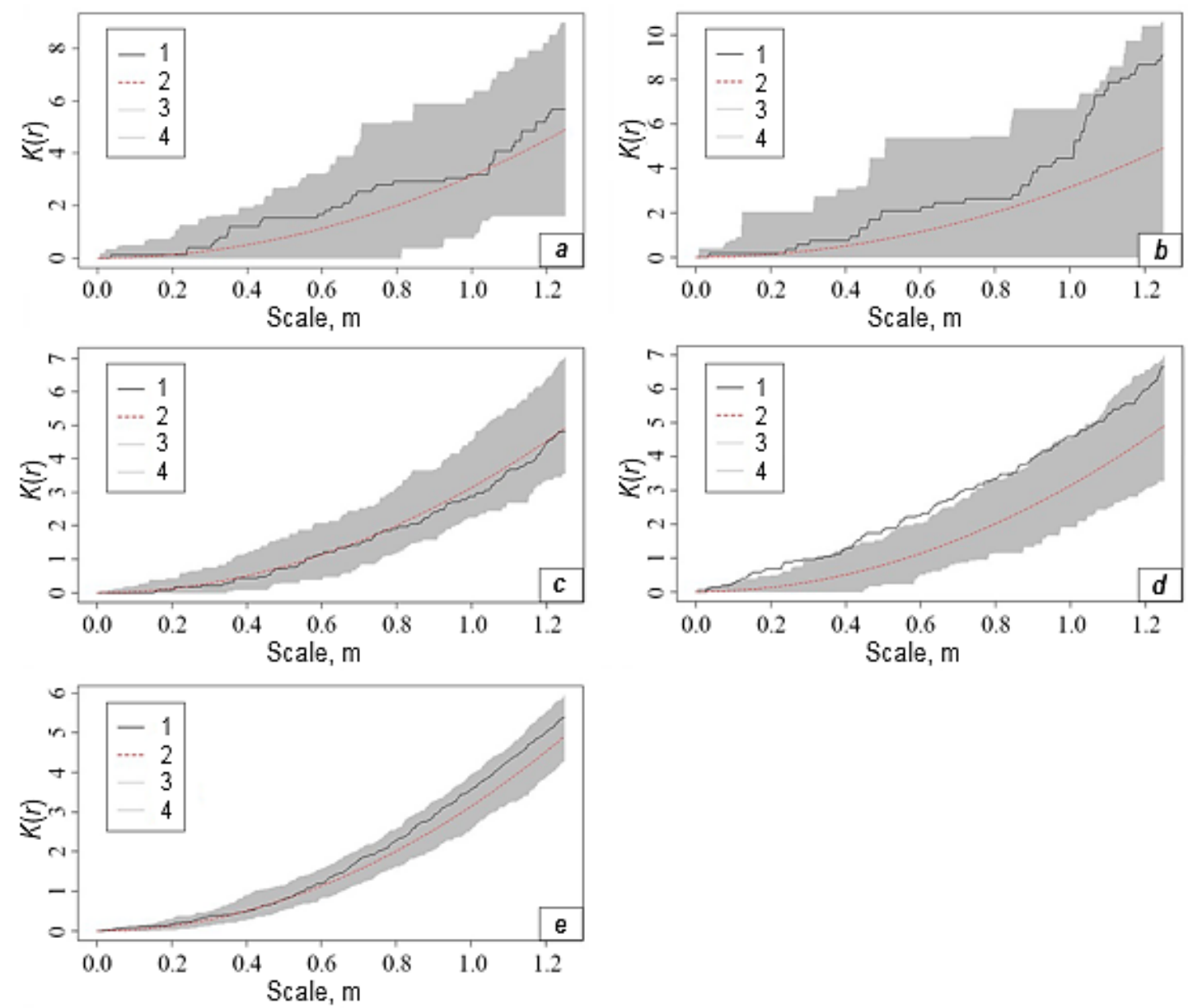

Fig. 2. Test result of the $K$ Function on the basis of the ant mound coordinates:

$1-\hat{K}_{o b s}(r)$, the observation value; $2-K_{\text {theo }}(r)$, the theoretical value;

$3-\hat{K}_{h i}(r)$, the upper envelope; $4-\hat{K}_{l o}(r)$, the lower envelope

Puс. 2. Результат проверки по функции К на основе расположения муравейников на пяти пробных точках:

1 - $\hat{K}_{\text {obs }}(r)$, в результате наблюдения; 2 - $K_{\text {theo }}(r)$, теоретическое значение; $3-\hat{K}_{h i}(r)$, верхняя кривая; $4-\hat{K}_{l o}(r)$, нижняя кривая

establish the correlation model of plant quantity and biomass and ant mound distribution. The results showed that on the scale of $5 \mathrm{~m} \times 5 \mathrm{~m}$, the mound distributions of the bright black ant in quadrat $1-3$ and 5 were random, and that in quadrat 4 was clustered. Generally speaking, the spatial distribution pattern of ant mound will change with a series of ecological factors including vegetation and soil conditions. When the surface environment and soil environment are more conducive to the nest settlement of ants, the aggregation degree of ant mound will increase, and more tend to cluster distribution [7]. However, the point pattern analysis method we chose ignored the environmental heterogeneity, so the cluster distribution of ant nest in quadrat 4 was probably due to its favorable geographical location for the settlement of bright black ants.
Ants, as the most widely distributed species and quantitative social insects on the earth, are socially ordered and efficient in foraging. To acquire the efficiency, ants adjust their foraging strategies and nesting positions to the resource distribution. Supposing the distribution of plants is greatly affected by environmental factors such as water and soil, the distribution of ant mounds in turn may be more affected by food resources. Thus, we hypothesized that the distribution of ant mounds is related to the distribution of plants species. In this survey, we found that plant biodiversity or most of the plant species had little impact on ant mound, with an almost no significant relationship. However, the total biomass of Artemisia frigida, Carex duriuscula and Oxytropis sylvestris had a more significant correlation with the numbers of nearby ant mounds. 
Ван Сюй, Ху Цинси, Кун Вэйчжэн и др. Корреляционный анализ между размещением...

Wang Xu, Hu Qingxi, Kong Weizheng, et al. The correlation analysis between ant mounds...

Table 1. Correlation analysis of plant biomass and the distribution of ant mounds

Таблица 1. Корреляционный анализ между биомассой растений и распределением муравейников

\begin{tabular}{|c|c|c|c|c|c|c|c|c|}
\hline \multirow{2}{*}{$\begin{array}{c}\text { Plant } \\
\text { ID }\end{array}$} & \multirow{2}{*}{ Scientific name } & \multicolumn{3}{|c|}{ Plant biomass in each quadrat, $g$} & \multirow{2}{*}{$\begin{array}{c}\text { Correlation } \\
\text { coefficient } \rho\end{array}$} & \multirow{2}{*}{$P$ value } \\
\cline { 3 - 8 } & & 1 & 2 & 3 & 4 & 5 & \\
\hline 1 & Agropyron cristatum & 79.2 & 2.4 & 9.6 & 36 & 228.6 & 0.206 & 0.304 \\
\hline 2 & Allium ramosum & 0 & 0 & 0 & 0 & 37.1 & 0.384 & 0.86 \\
\hline 3 & Allium schoenoprasum & 0 & 0 & 0.9 & 0 & 0 & -0.014 & 0.92 \\
\hline 4 & Allium tenuissimum & 0 & 0 & 0 & 1.1 & 0 & 0.008 & 0.785 \\
\hline 5 & Artemisia commutata & 149.6 & 58.3 & 138.6 & 80.3 & 0 & -0.072 & 0.066 \\
\hline 6 & Artemisia frigida & 0 & 0 & 0 & 0 & 433.6 & 0.442 & 0.038 \\
\hline 7 & Aster alpinus & 67.5 & 192.5 & 220 & 247.5 & 0 & -0.123 & 0.967 \\
\hline 8 & Bupleurum scorzonerifolium & 121.8 & 151.2 & 56.7 & 178.5 & 3.2 & -0.206 & 0.585 \\
\hline 9 & Caragana pygmaea & 0 & 0 & 0 & 0 & 17.4 & 0.256 & 0.377 \\
\hline 10 & Carexduriuscula & 269.5 & 21.7 & 60.9 & 128.8 & 0 & -0.367 & 0.029 \\
\hline 11 & Carum carvi & 1.5 & 9 & 22.5 & 15 & 0 & 0.025 & 0.669 \\
\hline 12 & Cleistogenes squarrosa & 0 & 0 & 0 & 0 & 15 & 0.243 & 0.162 \\
\hline 13 & Cymbaria daurica & 0 & 0 & 0 & 0 & 69.6 & 0.382 & 0.108 \\
\hline 14 & Eremogone meyeri & 379.5 & 21 & 432 & 175.5 & 152 & 0.074 & 0.902 \\
\hline 15 & Filifolium sibiricum & 46.5 & 1.1 & 15 & 3 & 0 & -0.248 & 0.733 \\
\hline 16 & Iris ruthenica & 2.4 & 0.6 & 1.8 & 3.6 & 0 & -0.085 & 0.733 \\
\hline 17 & Koeleria macrantha & 0 & 0 & 0 & 0 & 10 & 0.402 & 0.731 \\
\hline 18 & Orostachys spinosa & 208.8 & 72 & 180 & 122.4 & 2.8 & -0.003 & 0.256 \\
\hline 19 & Oxytropis sylvestris & 190.9 & 243.8 & 197.8 & 46 & 0 & -0.287 & 0.031 \\
\hline 20 & Potentilla bifurca & 0 & 0 & 0 & 0 & 31.5 & 0.265 & 0.94 \\
\hline 21 & Potentilla tanacetifolia & 2.2 & 2 & 0 & 1.1 & 0 & -0.08 & 0.846 \\
\hline 22 & Ptilotrichum sibiricum & 11.9 & 0.3 & 0.1 & 6.4 & 5.8 & 0.146 & 0.543 \\
\hline 23 & Pulsatilla ambigua & 130.5 & 109.5 & 124.5 & 85.5 & 0 & -0.281 & 0.219 \\
\hline 24 & Sanguisorba officinalis & 70.3 & 3.7 & 85.1 & 0 & 0 & -0.075 & 0.448 \\
\hline 25 & Thymus serpillum & 33 & 78.1 & 85.8 & 23.1 & 0 & -0.146 & 0.583 \\
\hline
\end{tabular}

Table 2. Correlation analysis between plant biodiversity index and ant mounds on scale of $5 \mathrm{~m} \times 5 \mathrm{~m}$ Таблица 2. Корреляционный анализ между индексом биоразнообразия растений и муравейниками в масштабе 5 м × 5 м

\begin{tabular}{|c|c|c|c|c|c|c|c|}
\hline \multirow{2}{*}{ Plant biodiversity } & \multicolumn{5}{|c|}{ Quadrat number } & \multirow{2}{*}{$\begin{array}{l}\text { Correlation } \\
\text { coefficient }\end{array}$} & \multirow{2}{*}{$P$ value } \\
\hline & 1 & 2 & 3 & 4 & 5 & & \\
\hline Shannon-Wiener & 2.162 & 2.207 & 2.174 & 2.271 & 1.973 & -0.8 & 0.107 \\
\hline Simpson & 0.841 & 0.87 & 0.847 & 0.871 & 0.825 & -0.68 & 0.21 \\
\hline
\end{tabular}

Table 3. Coefficients of regression model $\left(R^{2}=0.358\right)$

Таблица 3. Коэффициенты регрессионной модели $\left(R^{2}=0,358\right)$

\begin{tabular}{|c|c|c|c|c|c|}
\hline Modeling & $\begin{array}{c}\text { Regression } \\
\text { coefficients }\end{array}$ & $\begin{array}{c}\text { Standard } \\
\text { deviation }\end{array}$ & $\begin{array}{c}\text { Standard } \\
\text { coefficient }\end{array}$ & $T$ value & $P$ value \\
\hline Constant & 1.829 & 0.306 & - & 5.984 & 0 \\
\hline O.spinosa & 0.019 & 0.013 & 0.114 & 1.481 & 0.141 \\
\hline C.daurica & 0.179 & 0.115 & 0.219 & 1.563 & 0.121 \\
\hline P.ambigua & -0.063 & 0.039 & -0.125 & -1.605 & 0.111 \\
\hline C.squarrosa & -0.703 & 0.386 & -0.154 & -1.822 & 0.071 \\
\hline A.commutata & 0.047 & 0.025 & 0.174 & 1.906 & 0.059 \\
\hline A.frigida & 0.06 & 0.027 & 0.392 & 2.179 & 0.031 \\
\hline O.sylvestris & -0.062 & 0.026 & -0.238 & -2.396 & 0.018 \\
\hline C.duriuscula & -0.063 & 0.018 & -0.297 & -3.403 & 0.001 \\
\hline
\end{tabular}


Among them, the biomass of Artemisia frigida was positively related to the number of ant mounds. We suggested three possible reasons. First, the special properties of Artemisia frigida make it more attractive to more insects [17], providing sufficient food source for the bright black ant. Second, the root structure of Artemisia frigida stabilizes the rhizosphere soil ecosystem [18] which may be suitable for ants' living. Third, there may be a mutually beneficial relationship between Artemisia frigida and the bright black ant. The seed surface of some plants is covered with a nutritional part that attracts ants - oleosome [4]. Artemisia frigida may also provide nutrition for ants through other specific structures. Ants will in return protect the plants in the way of preventing or reducing from feeding and destruction of plants by other herbivores except honeydew insects. Such properties of Artemisia frigida may explain for the fact that the number of ant mounds was positively correlated with the total biomass of Artemisia frigida [19].

In addition, the individual total biomass of Carex duriuscula and Oxytropis sylvestris was negatively related to the number of ant mounds nearby. This phenomenon could be explained by the unfavorable properties of these two plants in forming a reciprocal symbiosis relationship with the bright black ant. According to the existing re- search, the bright black ant has reached nutritional symbiosis with Homoptera. The ants collect nectar from Homoptera, which is the nutrients excreted by Homoptera [20]. However, the covering villi of Oxytropis sylvestris which help resist insects and low temperature can reduce palatability [21]. Meanwhile Oxytropis sylvestris contains a variety of toxic alkaloids [22], making it not attractive to Homoptera insects. Therefore, this could be the reason for the finding that the nest distribution of bright black ants was individually negatively related to these two plants.

\section{Conclusion}

There is little research on the relationship between the spatial pattern of ant mound and plants. Thus, our research provides a different research idea for the interaction of animals and plants. Future research can increase the amount or coverage of quadrats or cover more plant species. Considering scale effect [23], it is necessary to investigate the spatial pattern distribution of ant nest on different scales, given this study is only based on the scale of $5 \mathrm{~m} \times 5 \mathrm{~m}$. Given that more information is obtained and considered, we could make one step further to build a bond between biological resources and tectonic motion, thus investigating how the unique ecosystem Baikal Lake evolved.

\section{References}

1. Petal J. The role of ants in ecosystems. In: Brian MV (eds.). Production ecology of ants and termites. Cambridge: Cambridge University Press; 1978. p.293-325.

2. Wu H, Lu X, Wu D, Song L, Yan X, Liu J. Ant mounds alter spatial and temporal patterns of $\mathrm{CO}_{2}, \mathrm{CH}_{4}$ and $\mathrm{N}_{2} \mathrm{O}$ emissions from a marsh soil. Soil Biology and Biochemistry. 2013;57:884-891. https://doi.org/10.1016/j.soilbio.2012.10.034

3. Wu H, Batzer DP, Yan X, Lu X, Wu D. Contributions of ant mounds to soil carbon and nitrogen pools in a marsh wetland of Northeastern China. Applied Soil Ecology. 2013;70:9-15. https://doi.org/10.1016/j.apsoil.2013.04.004

4. Zhang Z. Study on mutualism of ants with Codariocalyx motorius. Chongqing: Southwest Agricultural University; 2001. 145 p. (In Chinese)

5. Underwood EC, Fisher BL. The role of ants in conservation monitoring: if, when, and how. Biological Conservation. 2006;132(2):166-182. https://doi.org/10.1016/j.biocon.2006.03.022

6. Andersen AN, Hoffmann BD, Müller WJ, Griffiths AD. Using ants as bioindicators in land management: simplifying assessment of ant community responses. Journal of Applied Ecology. 2002;39(1):8-17. https://doi.org/10.1046/j.1365-2664.2002.00704.x
7. Wang S, Wang H, Li J. Distribution characteristics of ant mounds and correlating factors across different succession stages of tropical forests in Xishuangbanna. Biodiversity Science. 2016;24(8):916-921. (In Chinese) https://doi.org/10.17520/biods.2016088

8. Wang R, Zhai B, Sun X. Spatio-temporal dynamics of the first generation larvae of Laodelphax striatellus Fallén in wheat field. Acta Ecologica Sinica. 2007;27(11):4536-4546. (In Chinese) https://doi.org/10.3321/j.issn:1000-0933.2007.11.020

9. Zhang J. Quantitative Ecology. Beijing: Science Press; 2011. 372 p. (In Chinese)

10. Liu T, Yue Y, Li G, Wu Y, Lv J. Studies on spatial point pattern of three typical communities in lowland between dunes of Hunshandake sandy land. Journal of Inner Mongolia Forestry Science and Technology. 2019;45(2):16-21. (In Chinese) https://doi.org/10.3969/ j.issn.1007-4066.2019.02.004

11. Ripley BD. The second-order analysis of stationary point processes. Journal of Applied Probability. 1976;13(2):255-266. https://doi.org/10.2307/3212829

12. Baddeley A, Turner R. Spatstat: an R package for analyzing spatial point patterns. Journal of Statistical Software. 2005;12(6):1-42. https://doi.org/10.18637/jss.v012.i06 
13. Pan L, Kwong S, Liu Y, Zhang X, Yang X, Shan D, et al. Tree competition, spatial pattern, and regeneration of a Mongolian pine natural forest in the southern geographical edge. Acta Ecologica Sinica. 2019;39(10):3687-3699. (In Chinese) https://doi.org/10.5846/stxb201804270955

14. Robinson A. Randomization, bootstrap and Monte Carlo methods in biology. Journal of The Royal Statistical Society Series A-statistics in Society. 2007;170(3):856. https://doi.org/10.1111/j.1467-985X.2007.00485_5.x

15. Wang P, Li F, Yang Q, Wang F. Point pattern analysis of spatial distribution of ragweed population in Jiangxi Province based on Ripley's K function and Taylor's power law. Journal of Plant Protection. 2019;46(1):130-135. (In Chinese) https://doi.org/10.13802/j.cnki.zwbhxb.2019.2019916

16. Wang X, An S. The preliminary study on grassland restoration guidance by spearman rank correlation coefficient. Proceedings of Chinese Grassland Society 2013 Annual Conference. 2013;10:221-230. (In Chinese)

17. Yu F. Vegetation growth based on MODIS and the relationship between vegetation and grasshoppers of Grasshoppers Plague Areas in Aletai. Urumqi: Xinjiang Normal University; 2008. 47 p. (In Chinese)

18. Zang $X$, Zhang $H$, Wang $X$, Ma $Y$, Bao $T$, Zhang $R$, et al. Effects of grazing on microbial community structure diversity in rhizosphere soil of Artemisia frigida. Acta Agrestia Sinica. 2017;25(5):982-992. (In Chinese) https://doi.org/10.11733/j.issn.1007-0435.2017.05.011

19. Zhang S, Zhang Y, Ma K. A review of protective ant-plant interaction and its mediation mechanism. Chinese Journal of Plant Ecology. 2010;34(11):13441353. (In Chinese) https://doi.org/10.3773/j.issn.1005264x.2010.11.012

20. Novgorodova TA. Organization of honeydew collection by foragers of different species of ants (Hymenoptera: Formicidae): effect of colony size and species specificity. European Journal of Entomology. 2015;112(4):688697. https://doi.org/10.14411/eje.2015.077

21. Zhao M, Sun M, Ding Q, Yu Y. Comparison on the fine apparent characteristics of four species of Oxytropis in Qinghai. Grassland and Turf. 2017;37(3):68-74. (In Chinese) https://doi.org/10.3969/j.issn.1009-5500.2017.03.011

22. Tan C, Liu L, Hu B, Tang H, Zhao B. Alkaloids from poisonous plant Oxytropis Ochrocephala. Progress in Veterinary Medicine. 2015;36(8):71-73. (In Chinese) https://doi.org/10.16437/j.cnki.1007-5038.2015.08.015

23. Chase JM. Spatial scale resolves the niche versus neutral theory debate. Journal of Vegetation Science. 2014;25(2):319-322. https://doi.org/10.1111/jvs.12159

\section{Библиографический список}

1. Petal J. The role of ants in ecosystems // Production ecology of ants and termites / eds. M.V. Brian. Cambridge: Cambridge University Press, 1978. P. 293-325.

2. Wu H., Lu X., Wu D., Song L., Yan X., Liu J. Ant mounds alter spatial and temporal patterns of $\mathrm{CO}_{2}, \mathrm{CH}_{4}$ and $\mathrm{N}_{2} \mathrm{O}$ emissions from a marsh soil // Soil Biology and Biochemistry. 2013. Vol. 57. P. 884-891. https://doi.org/10.1016/j.soilbio.2012.10.034

3. Wu H., Batzer D.P., Yan X., Lu X., Wu D. Contributions of ant mounds to soil carbon and nitrogen pools in a marsh wetland of Northeastern China // Applied Soil Ecology. 2013. Vol. 70. P. 9-15. https://doi.org/10.1016/j.apsoil.2013.04.004

4. Zhang Z. Study on mutualism of ants with Codariocalyx motorius. Chongqing: Southwest Agricultural University, $2001.145 \mathrm{p}$.

5. Underwood E.C., Fisher B.L. The role of ants in conservation monitoring: if, when, and how // Biological Conservation. 2006. Vol. 132. Iss. 2. P. 166-182. https://doi.org/10.1016/j.biocon.2006.03.022

6. Andersen A.N., Hoffmann B.D., Müller W.J., Griffiths A.D. Using ants as bioindicators in land management: simplifying assessment of ant community responses // Journal of Applied Ecology. 2002. Vol. 39. Iss. 1. P. 8-17. https://doi.org/10.1046/j.1365-2664.2002.00704.x

7. Wang S., Wang H., Li J. Distribution characteristics of ant mounds and correlating factors across different succession stages of tropical forests in Xishuangbanna // Biodiversity Science. 2016. Vol. 24. Iss. 8. P. 916-921. https://doi.org/10.17520/biods.2016088

8. Wang R., Zhai B., Sun X. Spatio-temporal dynamics of the first generation larvae of Laodelphax striatellus Fallén in wheat field // Acta Ecologica Sinica. 2007. Vol. 27. Iss. 11. P. 4536-4546. https://doi.org/10.3321/j.issn:1000-0933.2007.11.020
9. Zhang J. Quantitative Ecology. Beijing: Science Press, 2011.372 p.

10. Liu T., Yue Y., Li G., Wu Y., Lv J. Studies on spatial point pattern of three typical communities in lowland between dunes of Hunshandake sandy land // Journal of Inner Mongolia Forestry Science and Technology. 2019. Vol. 45. Iss. 2. P. 16-21. https://doi.org/10.3969/j.issn.10074066.2019.02.004

11. Ripley B.D. The second-order analysis of stationary point processes // Journal of Applied Probability. 1976. Vol. 13. Iss. 2. P. 255-266. https://doi.org/ $10.2307 / 3212829$

12. Baddeley A., Turner R. Spatstat: an R package for analyzing spatial point patterns // Journal of Statistical Software. 2005. Vol. 12. Iss. 6. P. 1-42. https://doi.org/ 10.18637/jss.v012.i06

13. Pan L., Kwong S., Liu Y., Zhang X., Yang X., Shan D., et al. Tree competition, spatial pattern, and regeneration of a Mongolian pine natural forest in the southern geographical edge // Acta Ecologica Sinica. 2019. Vol. 39. Iss. 10. P. 3687-3699. https://doi.org/ 10.5846/stxb201804270955

14. Robinson A. Randomization, bootstrap and Monte Carlo methods in biology // Journal of the Royal Statistical Society Series A-statistics in Society. 2007. Vol. 170. Iss. 3. P. 856. https://doi.org/10.1111/j.1467-985X.2007. 00485_5.x

15. Wang P., Li F., Yang Q., Wang F. Point pattern analysis of spatial distribution of ragweed population in Jiangxi Province based on Ripley's K function and Taylor's power law // Journal of Plant Protection. 2019. Vol. 46. Iss. 1. P. 130-135. https://doi.org/10.13802/j.cnki. zwbhxb.2019.2019916

16. Wang X., An S. The preliminary study on grassland restoration guidance by spearman rank correlation 
coefficient // Proceedings of Chinese Grassland Society 2013 Annual Conference. 2013. Vol. 10. P. 221-230.

17. Yu F. Vegetation growth based on MODIS and the relationship between vegetation and grasshoppers of Grasshoppers Plague Areas in Aletai. Urumqi: Xinjiang Normal University, 2008. $47 \mathrm{p}$.

18. Zang X., Zhang H., Wang X., Ma Y., Bao T., Zhang R., et al. Effects of grazing on microbial community structure diversity in rhizosphere soil of Artemisia frigida // Acta Agrestia Sinica. 2017. Vol. 25. Iss. 5. P. 982-992. https://doi.org/10.11733/j.issn.1007-0435.2017.05.011

19. Zhang S., Zhang Y., Ma K. A review of protective ant-plant interaction and its mediation mechanism // Chinese Journal of Plant Ecology. 2010. Vol. 34. Iss. 11. P. 1344-1353. https://doi.org/10.3773/j.issn.1005$264 \times .2010 .11 .012$

20. Novgorodova T.A. Organization of honeydew col- lection by foragers of different species of ants (Hymenoptera: Formicidae): effect of colony size and species specificity // European Journal of Entomology. 2015. Vol. 112. Iss. 4. P. 688-697. https://doi.org/10.14411/eje.2015.077

21. Zhao M., Sun M., Ding Q., Yu Y. Comparison on the fine apparent characteristics of four species of Oxytropis in Qinghai // Grassland and Turf. 2017. Vol. 37. Iss. 3. P. 68-74. https://doi.org/10.3969/j.issn.10095500.2017 .03 .011

22. Tan C., Liu L., Hu B., Tang H., Zhao B. Alkaloids from poisonous plant Oxytropis Ochrocephala // Progress in Veterinary Medicine. 2015. Vol. 36. Iss. 8. P. 71-73. https://doi.org/10.16437/j.cnki.1007-5038.2015.08.015

23. Chase J.M. Spatial scale resolves the niche versus neutral theory debate /I Journal of Vegetation Science. 2014. Vol. 25. Iss. 2. P. 319-322. https://doi.org/ $10.1111 /$ jvs. 12159

\section{Authorship criteria / Критерии авторства}

Xu Wang, Qingxi Hu, Weizheng Kong, Chenyang Zhang, Shan Jia, Yuan Chang, Wei Deng, Andrey V. lishtva, Victor G. Shilenkov, Zhongqiu Li, Xingjun Tian are the authors of the article, hold equal copyright and bear equal responsibility for plagiarism.

Ван Сюй, Ху Цинси, Кун Вэйчжэн, Чжан Чэньян, Цзя Шань, Чан Юань, Дэн Вэй, Лиштва А.В., Шиленков В.Г., Ли Чжунцю, Тянь Синзюнь написали статью, имеют равные авторские права и несут одинаковую ответственность за плагиат.

\section{Responsibility for plagiarism / Конфрликт интересов}

The authors declare that there is no conflict of interest regarding the publication of this article.

Авторы заявляют об отсутствии конфликта интересов.

All authors have read and approved the final version of this manuscript.

Все авторы прочитали и одобрили окончательный вариант рукописи.

\section{Information about the authors / Сведения об авторах}

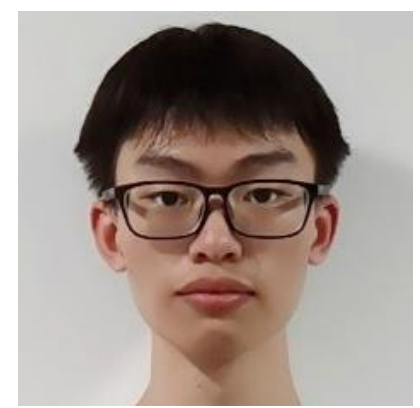

\section{Xu Wang,}

Student,

School of Life Science,

Nanjing University,

163 Xianlin Ave, Nanjing 210023, China,

e-mail: 171850537@smail.nju.edu.cn

\section{Ван Сюй,}

студент,

Школа естественных наук,

Нанкинский университет,

210023 , г. Нанкин, просп. Сяньлинь, 163, Китай,

e-mail: 171850537@smail.nju.edu.cn

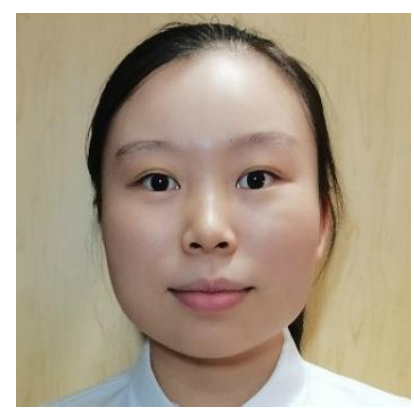

\section{Qingxi Hu,}

Student,

School of Life Science,

Nanjing University,

163 Xianlin Ave, Nanjing 210023, China,

e-mail: hqx.nju@foxmail.com

\section{Ху Цинси,}

студентка,

Школа естественных наук,

Нанкинский университет,

210023 , г. Нанкин, просп. Сяньлинь, 163, Китай,

e-mail:hqx.nju@foxmail.com 


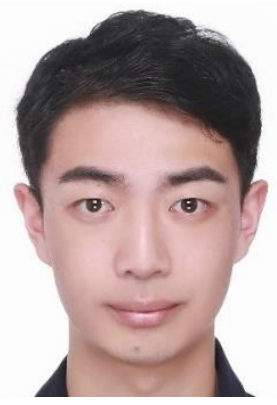

\section{Weizheng Kong,}

Student,

School of Life Science,

Nanjing University,

163 Xianlin Ave, Nanjing 210023, China,

e-mail: lyevkong@163.com

\section{Кун Вэйчжэн,}

студент,

Школа естественных наук,

Нанкинский университет,

210023, г. Нанкин, просп. Сяньлинь, 163, Китай, e-mail: lyevkong@163.com

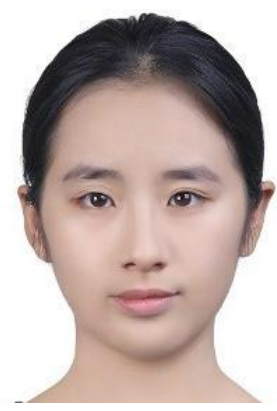

\section{Chenyang Zhang,}

Student,

School of Life Science,

Nanjing University,

163 Xianlin Ave, Nanjing 210023, China,

e-mail: 1524892891@qq.com

Чжан Чэньян,

студентка,

Школа естественных наук,

Нанкинский университет,

210023, г. Нанкин, просп. Сяньлинь, 163, Китай, e-mail:1524892891@qq.com

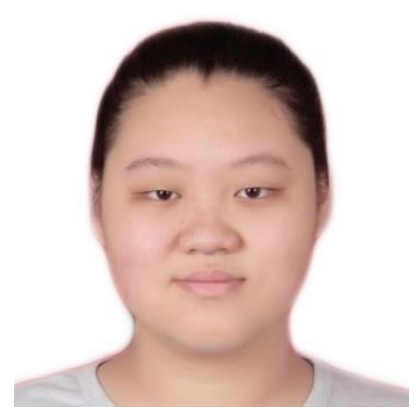

\section{Shan Jia,}

Student,

School of Life Science,

Nanjing University,

163 Xianlin Ave, Nanjing 210023, China,

e-mail:1160263491@qq.com

Цзя Шань,

студентка,

Школа естественных наук,

Нанкинский университет,

210023, г. Нанкин, просп. Сяньлинь, 163, Китай, e-mail:1160263491@qq.com

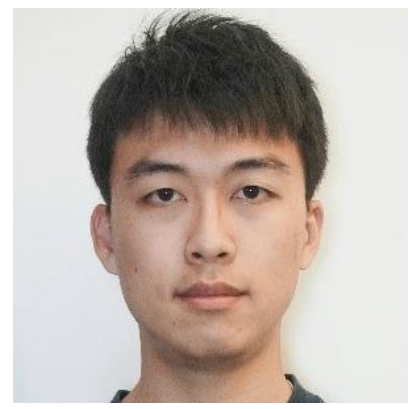

\section{Yuan Chang,}

Student,

School of Life Science,

Nanjing University,

163 Xianlin Ave, Nanjing 210023, China,

e-mail:cy_kn@foxmail.com

Чан Юань,

студент,

Школа естественных наук,

Нанкинский университет,

210023, г. Нанкин, просп. Сяньлинь, 163, Китай, e-mail:cy_kn@foxmail.com

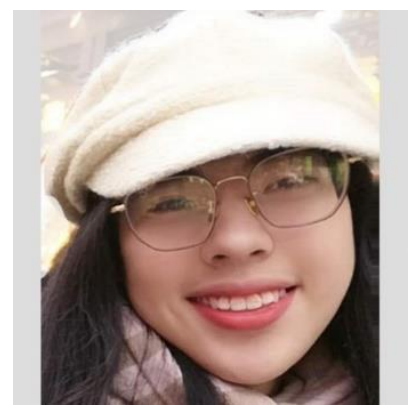

Wei Deng,

Student,

School of Life Science,

Nanjing University,

163 Xianlin Ave, Nanjing 210023, China,

e-mail: 171850064@smail.nju.edu.cn

Дэн Вэй,

студентка,

Школа естественных наук,

Нанкинский университет,

210023, г. Нанкин, просп. Сяньлинь, 163, Китай,

e-mail:171850064@smail.nju.edu.cn 


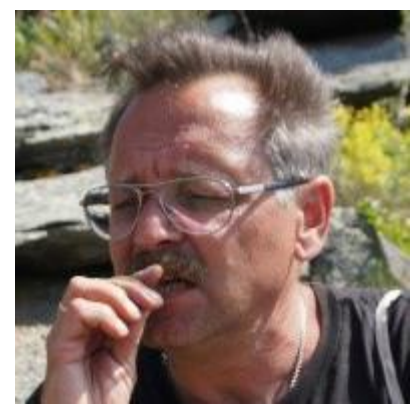

\section{Andrey V. lishtva,}

Cand. Sci. (Biol.), Associate Professor, Head of the Department of Botany, Irkutsk State University,

1 Karl Marx St., Irkutsk 664003, Russia, e-mail: lishtva@rambler.ru

Лиштва Андрей Владимирович, кандидат биологических наук, доцент, заведующий кафедрой ботаники, Иркутский государственный университет, 664003, г. Иркутск, ул. Карла Маркса, 1, Россия, e-mail: lishtva@rambler.ru

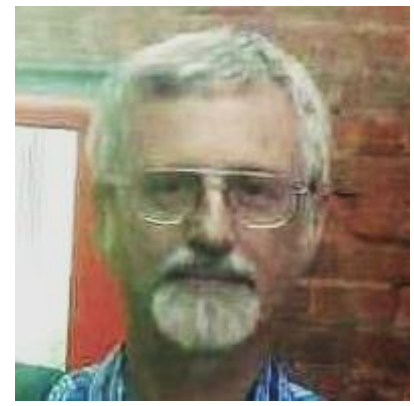

\section{Victor G. Shilenkov,}

Cand. Sci. (Biol.), Associate Professor,

Department of Hydrobiology and Invertebrate Zoology,

Irkutsk State University,

1 Karl Marx St., Irkutsk 664003, Russia,

e-mail: vgshilenkov@gmail.com

Шиленков Виктор Георгиевич,

кандидат биологических наук, доцент,

доцент кафедры гидробиологии и зоологии беспозвоночных,

Иркутский государственный университет

664003, г. Иркутск, ул. Карла Маркса, 1, Россия,

e-mail:vgshilenkov@gmail.com

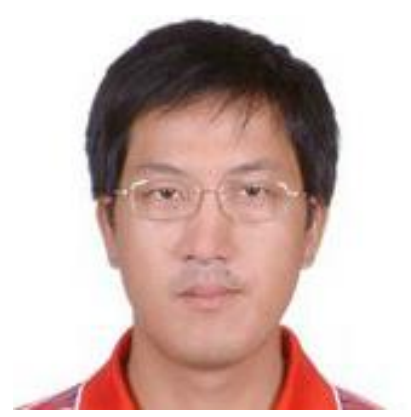

\section{Zhongqiu Li,}

Associate Professor,

School of Life Science,

Nanjing University,

163 Xianlin Ave, Nanjing 210023, China,

$\triangle$ e-mail: lizq@nju.edu.cn

Ли Чжунцю,

доцент,

Школа естественных наук,

Нанкинский университет,

210023, г. Нанкин, просп. Сяньлинь, 163, Китай,

$\triangle$ e-mail: lizq@nju.edu.cn

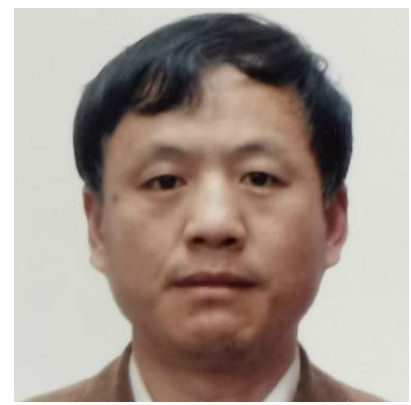

\section{Xingjun Tian,}

Professor,

School of Life Science,

Nanjing University,

163 Xianlin Ave, Nanjing 210023, China,

$\triangle$ e-mail: tianxj@nju.edu.cn

\section{Тянь Синзюнь,}

професссор,

Школа естественных наук,

Нанкинский университет,

210023, г. Нанкин, просп. Сяньлинь, 163, Китай,

$\triangle$ e-mail: tianxj@nju.edu.cn 